\title{
POZIOM ZADOWOLENIA MIESZKAŃCÓW WSI Z ŻYCIA NA WSI W ŚWIETLE BADAŃ EMPIRYCZNYCH
}

\section{SATISFACTION LEVEL OF RURAL INHABITANTS CONCERNING PLACE OF RESIDENCE IN LIGHT OF EMPIRICAL RESEARCH}

\section{Jan SIKORA}

Uniwersytet Ekonomiczny w Poznaniu

Wydział Ekonomii

al. Niepodległości 10, 61-875 Poznań

sikorajan@interia.pl

Zarys treści: Podstawowymi czynnikami determinującymi poziom zadowolenia mieszkańców wsi z zamieszkiwania na swoim terenie, a nie w mieście są elementy infrastruktury techniczno-użytkowej i społecznej. Uczestnictwo Polski w Unii Europejskiej stwarza duże nadzieje na poprawę tej infrastruktury na obszarach wiejskich. Celem artykułu jest ukazanie stanu zadowolenia i niezadowolenia mieszkańców wsi z warunków swojego życia. Dla celów porównawczych charakterystyka oceny przeprowadzona została dla roku 2005 i 2013. Jej wyniki wskazują, że wraz ze wzrostem stażu Polski w Unii Europejskiej, zgodnie z opinią mieszkańców wsi, wzrastają problemy związane ze słabszym funkcjonowaniem infrastruktury społecznej, a nie techniczno-użytkowej. Niezależnie jednak od wielu jeszcze niedostatków jednej i drugiej infrastruktury mieszkańcy wsi wykazują wysoki poziom zadowolenia z zamieszkiwania w swoich miejscowościach.

Podstawą napisania artykułu była analiza literatury przedmiotu oraz przede wszystkim wtórnych materiałów zawierających wyniki ogólnopolskich badań empirycznych, prezentowanych w raportach badawczych. Wykorzystano również analizę innych materiałów źródłowych.

Słowa kluczowe: zadowolenie, niezadowolenie, mieszkańcy wsi, opinie.

\section{Wprowadzenie}

Obszary wiejskie w Polsce (tereny położone poza granicami administracyjnymi miast) zajmują około 93\% powierzchni kraju. Mieszka na nich 38\% ogółu ludności. Średnio w krajach Unii Europejskiej na obszarach wiejskich mieszka 17\% ogółu ludności. Od 2003 r. utrzymuje się trend dodatniego salda migracji z miast na wieś. Według prognoz GUS udział ludności miejskiej w Polsce ogółem będzie się sukcesywnie zmniejszać na rzecz ludności wiejskiej. Wynika to m.in. z tego, że obszary wiejskie są największym beneficjentem pomocy wspólnotowej, zmierzającej do poprawy poziomu życia ich mieszkańców. Wsparcie z budżetu Unii Europejskiej przyczyniło się do realizacji wielu inwestycji, w tym infra- 
struktury drogowej i ochrony środowiska. Społeczność wiejska doceniła korzyści płynące z walorów przyrodniczych i podjęła na szerszą skalę między innymi rozwój działalności turystyczno-rekreacyjnej, wychodząc tym sposobem naprzeciw rosnącym oczekiwaniom i potrzebom mieszkańców miast. Na kierunek migracji na wieś mają również wpływ wyższe i rosnące koszty utrzymania w mieście. Sytuacje te powodują, że wyraźnie wzrasta atrakcyjność wsi jako miejsca stałego zamieszkania (Informacja... 2008, s. 6).

Obszary wiejskie kumulują jednak większość społeczno-gospodarczych problemów Polski: bezrobocie, niskie dochody, niski poziom wykształcenia, biedę, niski standard wyposażenia gospodarstw domowych, ograniczony dostęp do takich dóbr, jak: zdrowie, kultura, wykształcenie, prestiż społeczny (Fedyszak-Radziejewska 2006, s. 7). Problemy te łączą się ze słabo rozwiniętą na obszarach wiejskich infrastrukturą techniczno-użytkową i społeczną, z sytuacją ekonomiczną i demograficzną ich mieszkańców. Wszystko to rzutuje na stan zadowolenia i niezadowolenia ludności wiejskiej.

Zadowolenie z czegoś, np. z miejsca zamieszkania, z pracy, jako kategoria socjopsychologiczna, jest wypadkową wielu czynników materialnych i pozamaterialnych. Jest to stan równowagi pomiędzy potrzebami i oczekiwaniami mieszkańców wobec miejsca zamieszkania, pracowników wobec pracy a ich zaspokojeniem. Zadowolenie jest wykładnikiem i jednocześnie wyznacznikiem określonych postaw wobec sytuacji i zjawisk, instytucji, środowiska pracy i zamieszkania oraz przebywających tam ludzi. Jest funkcją wynikających stąd korzyści i strat oraz przyszłych pragnień i oczekiwań. Inaczej mówiąc, stanowi wypadkową satysfakcji z tego, co się ma i niezadowolenia z tego, czego się jeszcze nie ma (Januszek i Sikora 2008, s. 178).

Zadowolenie lub niezadowolenie mieszkańców wsi jest zatem wypadkową wielu składowych obiektywnych i subiektywnych elementów środowiska wiejskiego. Wyraża identyfikację oczekiwań mieszkańców wsi z swoim środowiskiem, skalę zaspokojenia ich potrzeb oraz perspektywy zmiany na lepsze warunków materialnych i niematerialnych tego środowiska.

O zadowoleniu lub niezadowoleniu z warunków życia na wsi decyduje wiele czynników. Dotyczą one sfery życia gospodarczego, społecznego i przyrodniczego. Pomimo iż w ciągu ostatnich lat daje się zauważyć duży postęp w każdej z tych dziedzin, potrzeby wsi są nadal ogromne. Polska wieś różni się od przeciętnej wsi w krajach Unii Europejskiej, gdzie przeważają wsie duże, o zwartej zabudowie, ułatwiającej podejmowanie skutecznych działań gospodarczych i socjalnych. W polskiej sieci osadniczej, choć zróżnicowanej regionalnie, dominują raczej pojedyncze gospodarstwa, odległe od innych, co utrudnia rozwój infrastruktury technicznej i społecznej, a tym samym nie sprzyja możliwościom rozwoju ekonomicznego i poprawy warunków życia ludności.

Takie elementy infrastruktury techniczno-użytkowej, jak: drogi, łączność, sieć elektroenergetyczna, zaopatrzenie w wodę, sieć kanalizacyjna, gazowa, komunikacyjna oraz infrastruktury społecznej, jak: domy kultury, kina, biblioteki, świetlice wiejskie, banki, szkoły, apteki, ośrodki zdrowia, obiekty sportowe, place zabaw, skanseny, muzea, poprawiają nie tylko standard życia mieszkańców. Przyczyniają się również do zwiększenia atrakcyjności inwestycyjnej i zapobiegają skutecznie odpływowi wykwalifikowanej siły roboczej do miast i za granicę (Sikora 2012, s. 44).

Poniżej przedstawiono krótką charakterystykę stanu infrastruktury techniczno-użytkowej i społecznej polskiej wsi. Uwzględniając sieć wodociągową, 70\% gospodarstw domowych jest podłączonych do wodociągów, a tylko 20\% do sieci kanalizacyjnej. Sła- 
bo rozwinięta sieć kanalizacyjna grozi zanieczyszczeniem gleby i wód gruntowych, wynikającym z odprowadzenia ścieków bezpośrednio do gruntów. Z kanalizacją na obszarach wiejskich łączy się oczyszczanie ścieków. Na tle innych krajów Unii Europejskiej wyposażenie wsi w oczyszczalnie ścieków w Polsce jest jednym z najniższych. W 2009 r. oczyszczalnie obsługiwały przeciętnie 64\% ludności kraju, z czego 82\% stanowili mieszkańcy miast, a zaledwie 18\% mieszkańcy wsi. W krajach Europy Zachodniej oczyszczalnie ścieków obsługują ponad 90\% ludności. Również stan dróg na obszarach wiejskich nie jest zadowalający. Głównym problemem jest nie tyle niedostateczna gęstość sieci dróg, lecz ich stan techniczny. Duży odsetek wiejskich dróg (33\%) ma nawierzchnię gruntową, przy czym ponad 59\% z nich to drogi gminne, na których utrzymanie gminy nie mają środków finansowych (Informacja... 2011, s. 19). Słabo wzrasta długość sieci gazowej (rozproszona sieć osadnicza na wsi czyni gazyfikację nieuzasadnioną ekonomicznie). Na tych terenach zastępczą rolę wobec systemu sieciowego pełni gaz dostarczany w butlach, którego dystrybucja na obszarach wiejskich jest bardzo dobrze zorganizowana. Przyjmuje się, że około 9,5\% wsi położonych poza strefą dostępności gazowych systemów sieciowych korzysta z tego rozwiązania. Wzrasta również dostępność i łatwość zaopatrzenia w gaz płynny, instalowany w zewnętrznych zbiornikach. Spada liczba abonentów korzystających z telefonii przewodowej, kosztem stale rosnącej liczby abonentów telefonii komórkowej. W infrastrukturze telekomunikacyjnej coraz większego znaczenia nabiera dostęp do internetu (Informacja...2011, s. 20).

Infrastruktura społeczna na obszarach wiejskich wymaga znacznego doinwestowania. Wyposażenie wiejskich ośrodków zdrowia jest niezadowalające i wymaga rozwoju oraz unowocześnienia laboratoriów, gabinetów rehabilitacyjnych, aparatury EKG. Konieczne jest zwiększenie zatrudnienia lekarzy na wsi. Liczba dzieci objęta opieką przedszkolną jest niższa niż w mieście i nadal się obniża. Władze lokalne co roku likwidują wiele wiejskich szkół podstawowych. Uznaje się, że poziom nauczania na wsi jest niższy niż w mieście. $\mathrm{Na}$ wsi nastąpiło znaczne zmniejszenie infrastruktury kulturalnej, zamykanie bibliotek i punktów bibliotecznych, kin wiejskich (Informacja... 2011, s. 7).

Uogólniając, należałoby zauważyć, iż tradycyjny model upowszechniania kultury na wsi, opierający się na działalności domów kultury, klubów, świetlic i bibliotek wiejskich przeżywa kryzys. Skromne warunki lokalowe, materialne i kadrowe oraz brak wsparcia finansowego ze strony samorządu terytorialnego czynią większość tych placówek niezdolnymi do przedstawienia oferty programowej, która zainteresowałaby mieszkańców wsi (Sikora 2014, s. 188).

Rozwój infrastruktury technicznej i społecznej na wsi jest ważnym elementem polityki społeczno-gospodarczej kraju. Dla wielu gmin wiejskich budowa nowej czy modernizacja istniejącej już infrastruktury technicznej i społecznej to bardzo poważne wyzwanie finansowe, trudne do zrealizowania ze środków własnych. Wsparcie w tym względzie przyniosły programy operacyjne dotowane z funduszy europejskich, np. Program Rozwoju Obszarów Wiejskich 2007-2013 (PROW) oraz Program Rozwoju Obszarów Wiejskich na lata 2014-2020. Programy te uwzględniają płaszczyzny działań poprawiające m.in. warunki życia i pracy mieszkańców wsi, tym samym wpływają na wzrost ich zadowolenia i minimalizowanie niezadowolenia z życia na wsi. 


\section{Cel i metoda badawcza}

Celem artykułu jest przedstawienie oceny, dokonanej przez mieszkańców wsi, poziomu zadowolenia i niezadowolenia wynikającego z dostępu do wszelkiego rodzaju osiągnięć cywilizacyjnych, jakie tworzą różne elementy infrastruktury techniczno-użytkowej i społecznej wsi. Wskazanie najważniejszych elementów tej infrastruktury, koniecznych do poprawy, które mogłyby zmniejszyć poziom niezadowolenia z życia na obszarach wiejskich.

Przyjętą podstawową metodą badawczą była analiza wtórnych materiałów empirycznych, zawierających wyniki ogólnopolskich badań prowadzonych od 2004 r. przez Ośrodki Badania Opinii Społecznej i Rynku na zlecenie Ministerstwa Rolnictwa i Rozwoju Wsi w Warszawie. Badania te dotyczą stanu świadomości rolników i mieszkańców wsi na temat problemów społeczno-ekonomicznych występujących w ich miejscu zamieszkania. Prowadzone są one z wykorzystaniem techniki wywiadu osobistego z kwestionariuszem ankietowym. Wywiad przeprowadzany jest przez wykwalifikowanych ankieterów na dwóch oddzielnych próbach: reprezentatywnej, kwotowo-celowej próbie rolników prowadzących gospodarstwo rolne oraz reprezentatywnej, losowej próbie pozostałych mieszkańców wsi. Ogółem przeprowadzonych zostaje corocznie 1500 wywiadów.

Próba rolników jest dystrybuowana zgodnie z rzeczywistym rozkładem gospodarstw rolnych ze względu na powierzchnię użytków rolnych oraz ze względu na województwo. Maksymalny błąd statystyczny dla próby rolników wynosi +/-3,4\%. Za mieszkańców wsi zostają uznane osoby na stałe zamieszkujące na terenach wiejskich, bez względu na źródło utrzymania bądź fakt posiadania (lub nie) gospodarstwa rolnego. Maksymalny błąd statystyczny dla próby mieszkańców wsi wynosi +/-3,8\%. Metodologicznie procedura badań wskazuje na reprezentatywność ich wyników w ujęciu ogólnopolskim oraz przy niektórych zagadnieniach także w podziale na regiony.

W artykule przedstawione zostały niektóre wyniki badań empirycznych, dotyczące omawianych zagadnień, zawarte w odpowiednich raportach (Polska wieś i rolnictwo... 2005, 2013). Badania wykonano na zlecenie Ministerstwa Rolnictwa i Rozwoju Wsi, Agencji Restrukturyzacji i Modernizacji Rolnictwa, Agencji Nieruchomości Rolnych, Kasy Rolniczego Ubezpieczenia Społecznego. Pierwsze badanie zrealizowane było przez firmę Research International Pentor, drugie przez firmę Bio Stat.

W artykule dodatkowo wykorzystano również metodę krytycznej analizy literatury oraz innych wtórnych materiałów źródłowych.

\section{Wyniki badań i dyskusja}

Problematyka zadowolenia i niezadowolenia mieszkańców wsi jest przedmiotem zainteresowań teoretyczno-empirycznych przedstawicieli socjologii wsi (Bukraba-Rylska 2008) oraz socjologii obszarów wiejskich (Gorlach 2004). Z badań tych wynika, że niezadowolenie mieszkańców wsi ze swojego miejsca zamieszkania i pracy było szczególnie widoczne przed przystąpieniem Polski do Unii Europejskiej. Literatura przedmiotu wskazuje, że rolnicy i mieszkańcy wsi niezmiernie krytycznie oceniali swoje położenie materialne, efekty transformacji systemowej w Polsce oraz działalność rządu w odniesieniu do spraw wsi i rolnictwa. Obok krytycyzmu występowało poczucie bezradności w nieprzejrzystym dla nich świecie mechanizmów rynkowych. Panowała nostalgia za rozbudowaną, regulacyj- 
ną i ochronną rolą państwa w odniesieniu do rolnictwa (Kocik 2001, s. 38). Sytuacje te powodowały, że określenia „transformacja”, „integracja”, „restrukturyzacja” kojarzyły się większości rolnikom z działaniami wymierzonymi przeciw nim. Powszechnie dominowało odczucie lęku przed przyszłością oraz występowała świadomość narastających trudności po przystąpieniu do Unii Europejskiej (Kocik 2001, s. 75).

Ocenę zadowolenia i niezadowolenia ze stanu warunków życia w postaci poziomu rozwiniętej infrastruktury techniczno-użytkowej i społecznej wyrażoną przez mieszkańców wsi w 2005 r. oraz dla porównania w 2013 r. przedstawiają ryc. 1, 2.

Wyniki badań wskazują, że w 2005 r., a więc krótko po wejściu Polski do Unii Europejskiej, „bolączką” mieszkańców wsi (rolników i nierolników), wpływającą na stan ich niezadowolenia, był niedostateczny rozwój infrastruktury technicznej i społecznej. Najczęściej narzekali oni na brak dostępu do sieci kanalizacyjnej (łącznie odpowiedzi „raczej niezadowolony” i „bardzo niezadowolony” - 49\%), brak dostępu do sieci gazowej-41\%, do usług - 42\%, do kultury i rozrywek na wsi - 52\%, brak możliwości podnoszenia kwalifikacji zawodowych, szkoleń - 37\%. Dla wielu mieszkańców wsi problemem były: możliwość studiowania przez dzieci - 26\%, problemy oświaty (brak szkół na wsi, duża odległość do najbliższej szkoły) i poziomu nauczania w szkole - 26\%, brak dostępnych środków transportu (autobusów, kolei) - 24\%, trudności z dostępem do opieki zdrowotnej - 23\%. Wyniki badań z 2005 r. wskazały również, że w większości opinii badanych w ostatnim roku w ich miejscowościach nie zrobiono nic w zakresie pomocy dla najbiedniejszych. Nie zorganizowano szkoleń i pomocy rolniczej, nie inwestowano w zwiększenie możliwości edukacyjnych dla ludzi młodych na wsi. Natomiast zadowolenie mieszkańców wsi (łącznie odpowiedzi „,bardzo zadowolony” i „raczej zadowolony”) z infrastruktury technicznej i społecznej dotyczyło np. powszechnego dostępu do telefonii stacjonarnej - 77\% i do sieci wodociągowej-73\%. Wieś w oczach mieszkańców wsi jest bezpieczną oazą zamieszkania, spokoju i ciszy - 76\% (ryc. 1).

Dla porównania przedstawiono opinie na temat infrastruktury techniczno-użytkowej wyrażone przez mieszkańców wsi w 2013 r. - po 8 latach członkostwa w strukturach unijnych. Z ryc. 2 wynika, że wraz ze wzrostem stażu Polski w Unii Europejskiej zwiększały się problemy infrastruktury społecznej w miejscu zamieszkania. Mieszkańcy wsi najczęściej narzekali (łącznie odpowiedzi „raczej niezadowolony” i „bardzo niezadowolony”) na: brak możliwości podnoszenia kwalifikacji zawodowych i poziomu wykształcenia osób dorosłych mieszkających na wsi - 42\%, brak dostępności do opieki nad osobami starszymi/zależnymi - 40\%, brak możliwości studiowania - 42\%, brak dostępności do opieki nad dzieckiem w wieku do 3 lat -35\%, brak dostępu do obiektów sportowych i rekreacyjnych - 30\% oraz brak dostępu do kultury i sztuki, dostępnych rozrywek - 26\%. Z elementów infrastruktury technicznej utrzymywała się opinia o braku dostępu do sieci gazowej - 33\% oraz braku dostępu do sieci kanalizacyjnej-27\%. Pojawił się nowy problem na wsi, a mianowicie brak dostępu do bankomatów - 36\%. Podobnie jak w opiniach wyrażanych w 2005 r., w 2013 r. mieszkańcy pozytywnie ocenili dostęp do sieci wodociągowej - 52\%, dostęp do Internetu - $48 \%$ oraz bezpieczeństwo zamieszkania na wsi - 51\%.

Ważnym aspektem życia na wsi jest dalszy rozwój infrastruktury techniczno-społecznej. Mimo że w ciągu ostatnich lat daje się zauważyć duży postęp za sprawą środków unijnych w zakresie dostępu i stanu jakości tej infrastruktury, to jednak potrzeby wsi są nadal ogromne. W badaniach, na które się powołuję, mieszkańcom wsi zadano pytanie: „Co Pana (i) zdaniem należy poprawić na obszarach wiejskich w Pana (i) powiecie w pierw- 
szej kolejności?”. Wyniki badań przedstawione na ryc. 3 wskazują, że w 2013 r. najpilniejszą kwestią do rozwiązania był dostęp do pozarolniczych miejsc pracy - 35\% i dostęp do opieki zdrowotnej-44\%. Inne ważne kwestie, które należałoby poprawić na obszarach wiejskich według badanych, to: dbałość o środowisko naturalne $-24 \%$, dostęp do opieki nad dzieckiem w wieku do 3 lat - 23\%, dostęp do obiektów sportowych i rekreacyjnych - 21\%, dostępność do opieki nad osobami starszymi/zależnymi - $21 \%$ oraz dostęp do kultury na wsi i rozrywek - 20\%. Zauważyć można, że na obszarach wiejskich dominują słabo rozwiązane problemy dotyczące infrastruktury społecznej.

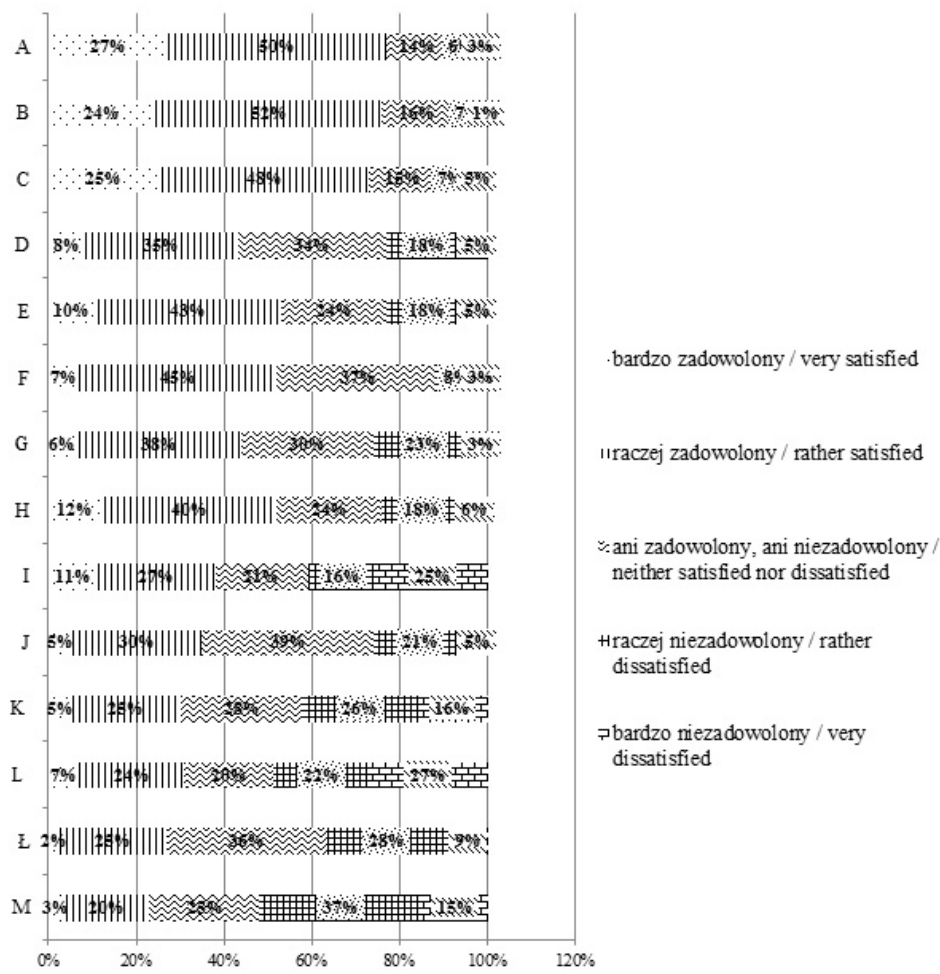

Ryc. 1. Ocena infrastruktury techniczno-społecznej dostępnej na wsi przez mieszkańców wsi w roku 2005 (\%), N = 1500 Evaluation of technical and social infrastructure available by residents of rural areas in 2005 (\%), N=1500 Ocena / Rating: A - dostępu do sieci telefonii stacjonarnej / access to fixed telephone lines; B - bezpieczeństwa w Pana(i) miejscowości / safety in your location; C - dostępu do sieci wodociągowej / access to water supply network; D - dostępu do opieki zdrowotnej / access to healthcare services; E - dostępu na wsi do placówek handlowych / access to commercial centers in rural areas, F - jakości pracy Pana(i) urzędu gminnego / quality of services provided by communal administration; G - oświaty, poziomu nauczania w szkole / education level at schools; $\mathrm{H}$ - dostępnych środków transportu (autobusów, kolei) / available means of transportation (buses, trains); I - dostępu do sieci gazowej / access to gas network; J - możliwości studiowania przez dzieci / opportunities to study for children; $\mathrm{K}$ - dostępu na wsi do usług / access to services in rural areas; $\mathrm{L}$ - dostępu do sieci kanalizacyjnej / access to sewerage system; $Ł$ - możliwości podnoszenia kwalifikacji zawodowych, szkoleń / opportunities for improving qualifications and professional trainings; $\mathrm{M}$ - kultury na wsi, dostępnych rozrywek / culture in rural areas, available entertainment.

Źródło/Source: Polska wieś i rolnictwo... (2005, s. 22). 


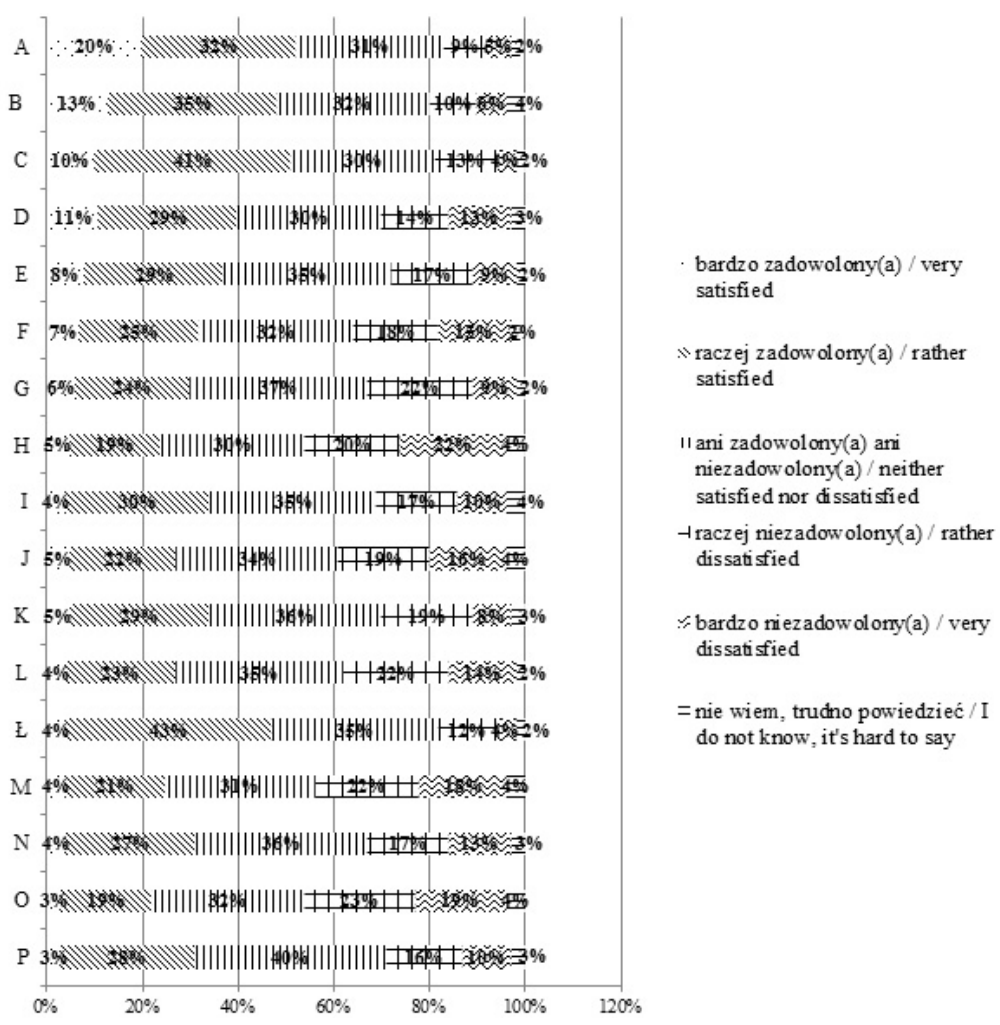

Ryc. 2. Ocena infrastruktury techniczno-społecznej dostępnej na wsi przez mieszkańców wsi w roku 2013 (\%), N = 1500 Evaluation of technical and social infrastructure available by residents of rural areas in 2013 (\%), N = 1500 Ocena / Rating: A - dostępu do sieci wodociągowej / access to water supply network; B - dostępu do internetu laccess to Internet; $C$ - bezpieczeństwa w Pana(i) miejscowości / safety in your location; D - dostępu do sieci kanalizacyjnej - access to sewerage system; E - możliwości dojazdu do innych miejscowości środkami komunikacji zbiorowej ( $\mathrm{np}$. dojazd do szkoły) / opportunities for commuting to other locations with means of public transportation (e.g. commuting to schools etc.); F - dostępu do sieci gazowej / access to gas network; G dostępu do banków, zakładów ubezpieczeniowych / access to banks and insurance companies; H - możliwości studiowania - opportunities for studying at universities; I - dostępu do opieki przedszkolnej / access to nursery schools; J - dostępu do opieki nad dzieckiem w wieku 3 lat / access to care for children aged 3 years; $\mathrm{K}$ oświaty, poziomu nauczania / education and education level; $L$ - dostępu do bankomatów - access to cash machines; $Ł$ - dostępu do opieki zdrowotnej / access to healthcare; M - dostępność do opieki nad osobami starszymi/zależnymi / access to care for the elderly/dependent people; N - dostępu do obiektów sportowych i rekreacyjnych / access to sport and recreation facilities; O - możliwości podnoszenia kwalifikacji zawodowych i poziomu wykształcenia osób dorosłych / opportunities for improving vocational qualifications and the level of education among adults; P - dostępu do kultury i sztuki, dostępnych rozrywek - access to culture, art and entertainment.

Źródło/Source: Polska wieś i rolnictwo... (2013, s. 22).

Na podstawie przedstawionych opinii, które są odbiciem obiektywnej sytuacji wsi, tworzy się nie najlepszy jej wizerunek jako środowiska zamieszkania, pracy i jakości życia. W sumie jednak zamieszkanie na wsi, a nie w mieście przynosi jej mieszkańcom zadowolenie. W przywoływanych badaniach spytano mieszkańców wsi (rolników i nierolników), czy są zadowoleni czy też niezadowoleni z tego, że mieszkają na wsi, a nie w mieście. Z wyników zaprezentowanych na ryc. 4 widać, że w ostatnich ośmiu latach, a więc po przystąpieniu do Unii Europejskiej, maleje niezadowolenie z zamieszkiwania na wsi (13\% w 2005 r. i 7\% w 2013 r.), a z kolei utrzymuje się na wysokim poziomie i wolno rośnie satysfakcja 


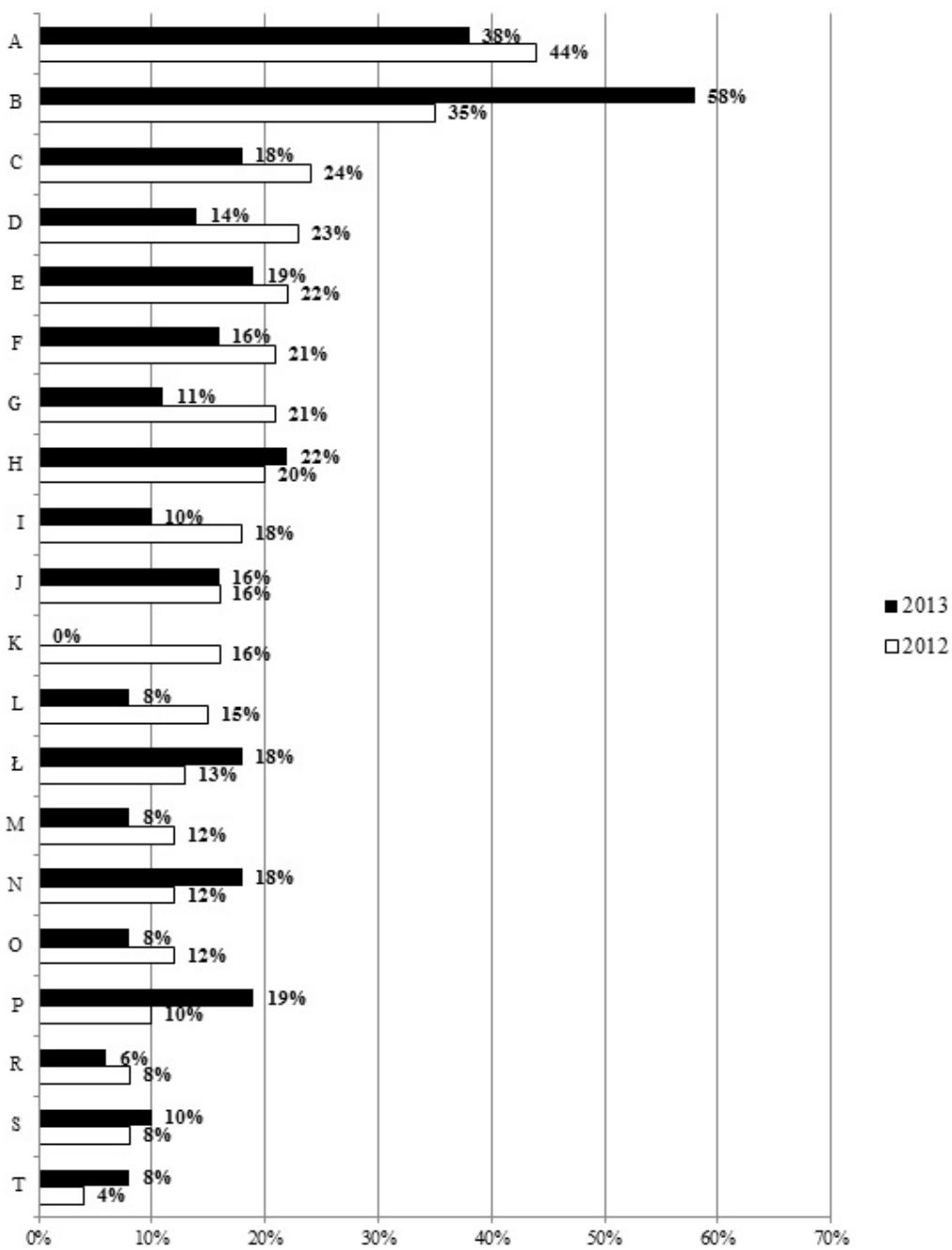

Ryc. 3. Najważniejsze kwestie do poprawy na wsi w opinii mieszkańców wsi (\%), $N=1500$

The most important issues requiring improvement in rural areas in the opinion of rural residents (\%), $N=1500$ A - dostęp do opieki zdrowotnej / access to healthcare; B - dostęp do pozarolniczych miejsc pracy / access to non-agricultural workplaces; C - dbałość o środowisko naturalne / care for the environment; D - dostęp do opieki nad dzieckiem w wieku 3 lat / access to care for children aged 3 years; E - dostęp do bezpiecznej i zdrowej żywności / access to safe and healthy food; F-dostęp do obiektów sportowych i rekreacyjnych / access to sport and recreation facilities; G - dostęp do opieki nad osobami starszymi/zależnymi / access to care for the elderly/dependent people; $\mathrm{H}$ - dostęp do kultury na wsi, dostępnych rozrywek / access to culture and entertainment in rural areas; I - jakość edukacji w szkole podstawowej i gimnazjum / quality of education in primary and junior high schools; J - dostęp do opieki przedszkolnej / access to nursery schools; K - możliwości dojazdu do innych miejscowości środkami komunikacji zbiorowej / opportunities for commuting to other locations with means of public transportation (e.g. commuting to work by bus); $L$ - dostęp do edukacji na poziomie wyższym niż przedszkolny / access to education at higher level than nursery schools; $Ł$ - poziom konkurencyjności i innowacyjności gospodarstw rolnych / level of competitiveness and innovativeness of households; $\mathrm{M}$ - dostęp do bankomatów / access to cash machines; N - dostęp do sieci kanalizacyjnej / access to sewerage system; O bezpieczeństwo / safety; P - dostęp do sieci gazowej / access to gas network; R - dostęp do banków i zakładów ubezpieczeniowych / access to banks and insurance companies; S - dostęp do internetu / access to Internet; T - dostęp do sieci wodociągowej - access to water supply network. Źródło/Source: Polska wieś i rolnictwo... (2013, s. 126). 
z życia na wsi (87\% w 2005 r. i 91\% w 2013 r.). Opinia ta dominuje u przedstawicieli wszystkich kategorii społecznych, niezależnie od wieku, wykształcenia czy dochodów. Dla badanych mieszkańców wsi miasto nie stanowi jednak atrakcyjnego miejsca do zamieszkania. W 2005 r. 79\% mieszkańców wsi nie wyraziło zamiaru przeprowadzenia się do miasta, nawet wtedy, gdyby mieli taką możliwość. W 2013 r. mieszkańców takich było 80\% (Polska wieś i rolnictwo... 2013).

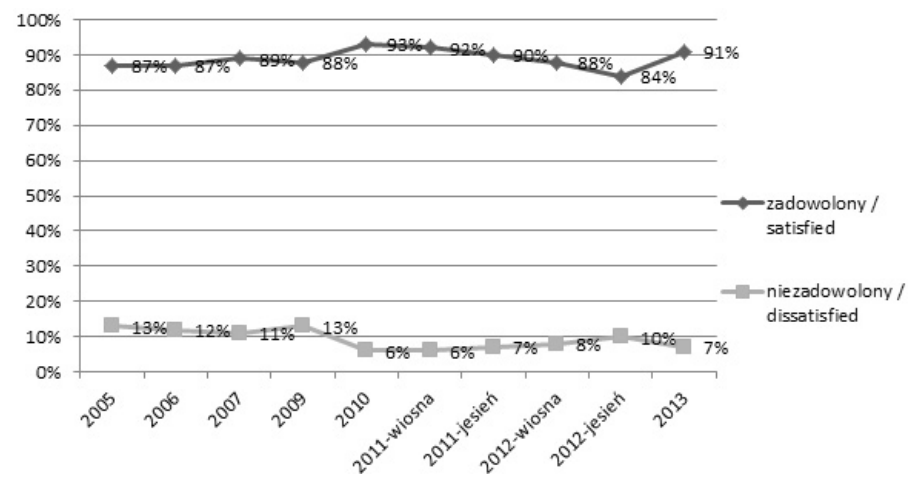

Ryc. 4. Opinie mieszkańców wsi na temat zadowolenia i niezadowolenia z życia na wsi (\%) N = 1500 Opinions of rural residents on satisfaction level concerning living in rural areas (\%) $N=1500$ Źródło/Source: Polska wieś i rolnictwo... (2013, s. 118).

Największy odsetek zadowolonych rolników znajduje się w regionie południowym (98\%), najmniejszy zaś w regionie północnym (87\%) i wschodnim (87\%). Największy odsetek nierolników zadowolonych z tego, że mieszka na wsi, znajduje się w regionie centralnym i południowym (po 94\%), najmniejszy zaś również w regionie północnym (83\%) i wschodnim (83\%) (ryc. 5). Pomimo tego, że na wsi należałoby jeszcze dużo zrobić w poprawie infrastruktury techniczno-użytkowej i społecznej, to jednak powyższe wyniki wskazują na poczucie optymizmu i przywiązania do swojej „małej ojczyzny i miejsca na ziemi” wśród mieszkańców wsi. Jest to istotny argument motywujący do doskonalenia warunków życia i pracy na wsi. Stanowi również podstawę poprawy dostępności do infrastruktury techniczno-społecznej obszarów wiejskich, która niewątpliwie determinuje motywację do podejmowania tej aktywności.

Tak wysoki stopień zadowolenia z zamieszkiwania oraz życia na wsi stanowi mocną subiektywną podstawę dla rozwijania kapitału społecznego, którego nie można budować w sytuacji niezadowolenia ludzi. Oczywiście, taka postawa stwarza potencjalną możliwość kształtowania więzi społecznej, w szczególności więzi rodzinnych oraz sąsiedzkich, które w środowisku wiejskim są tradycyjnie bardzo silne.

Wyrażane przez respondentów zadowolenie z jednej strony sprzyja w sensie subiektywnym utrzymaniu więzi społecznych jako składnika kapitału społecznego, kształtowaniu wewnątrzgrupowej lojalności, solidarności i zaufania do rodziny, grup sąsiedzkich, z drugiej jednak strony nie przedkłada się na rozwijanie innego składnika kapitału społecznego, tzn. wykorzystania jednostkowych powiązań i znajomości na tworzenie sieci społecznych, jakie współtworzą stowarzyszenia i organizacje społeczeństwa obywatelskiego.

Deklarowany przez mieszkańców wsi wysoki stopień zadowolenia z zamieszkania na wsi stwarza jednakże subiektywną, intencjonalną możliwość realizacji kapitału społecz- 


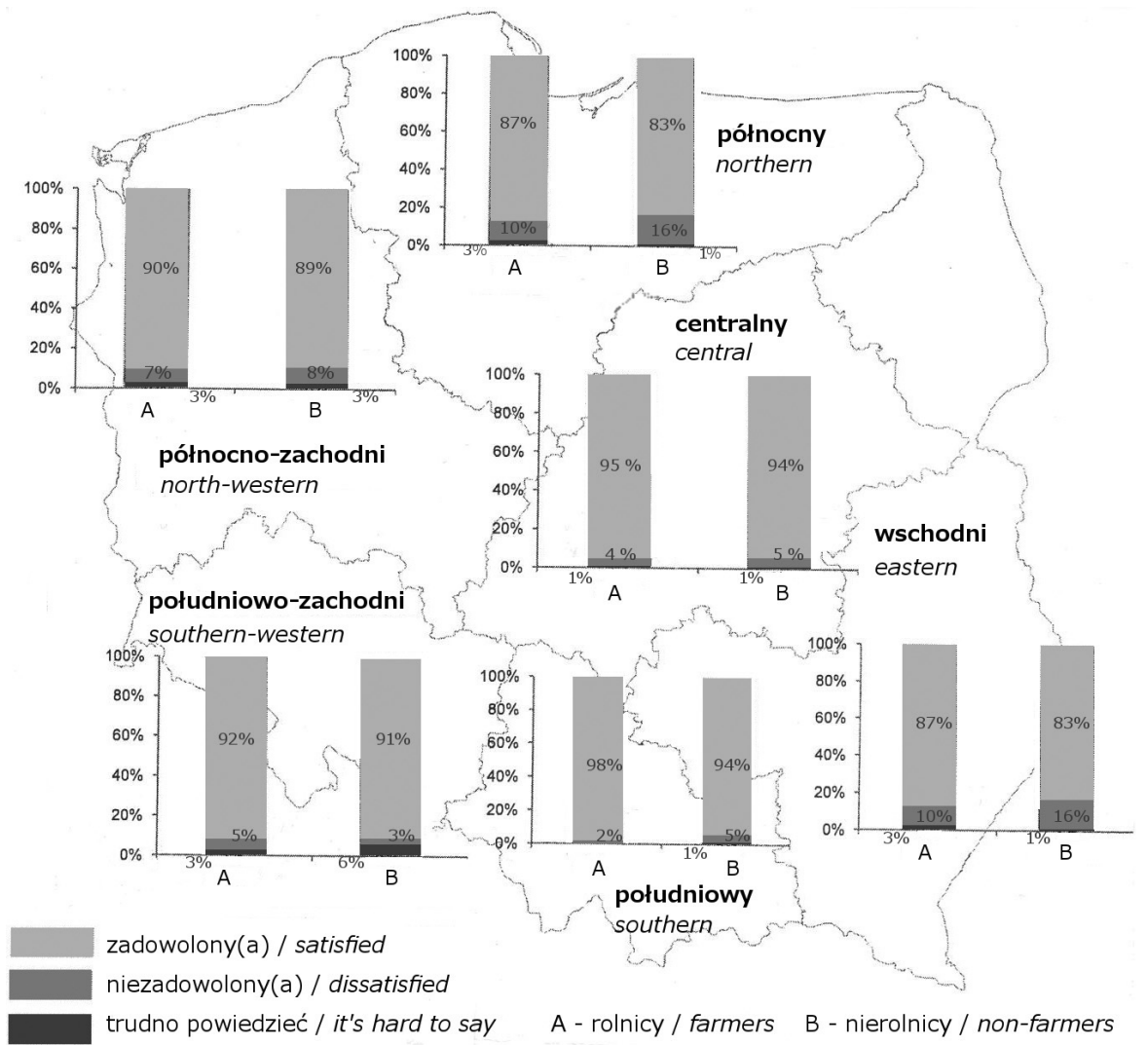

Ryc. 5. Opinie mieszkańców wsi na temat zadowolenia i niezadowolenia z mieszkania na wsi, a nie w mieście według regionów Polski (\%) N = 1500

Opinions of rural residents on satisfaction level concerning living in rural areas, opposed to living in cities by regions of Poland (\%) $N=1500$

Źródło/Source: Polska wieś i rolnictwo... (2013, s. 115).

nego, pod warunkiem, że w środowiskach wiejskich rozwinie się społeczeństwo obywatelskie, w którym jednostki będą angażować w pracę w stowarzyszeniach, organizacjach, nieformalnych grupach celowych.

\section{Zakończenie}

Obszary wiejskie, jak już wskazałem, zamieszkuje 38\% ogółu ludności kraju. Zatem warunki życia związane z infrastrukturą techniczno-użytkową i społeczną mieszkańców wsi determinujące ich zadowolenie, muszą podlegać procesom ustawicznej modernizacji.

Poprawa i doskonalenie warunków pracy i zamieszkania na wsi łączy się zatem z aktywizacją obszarów wiejskich. W tych działaniach istotną rolę muszą odegrać liderzy wiejscy, elity, działacze organizacji pozarządowych oraz wiejskiej inteligencji.

Wyrażane przez mieszkańców wsi opinie na temat problemów do rozwiązania i poprawy warunków zamieszkania na wsi tworzą podmiotową postawę obywatelską w wymiarze 
lokalnym. Wskazują na subiektywne przesłanki rozwoju aktywności gospodarczej i społecznej na wsi, które nadal powinno być „motorem” kształtowania zadowolenia z życia i mieszkania na tych obszarach. Natomiast Program Rozwoju Obszarów Wiejskich na lata 2014-2020, w którym zostały uwzględnione działania poprawy warunków pracy i życia mieszkańców wsi, powinien podlegać szerszemu monitoringowi i ocenie ewaluacyjnej.

\section{Literatura}

Bukraba-Rylska I., 2008, Socjologia wsi polskiej, Wydawnictwo Naukowe PWN, Warszawa.

Fedyszak-Radziejewska B., 2006, Wstęp, [w:] Proces demarginalizacji polskiej wsi. Programy pomocowe, liderzy, elity i organizacje pozarzqdowe, Instytut Spraw Publicznych, Warszawa.

Gorlach K., 2004, Socjologia obszarów wiejskich. Problemy i perspektywy, Wydawnictwo Naukowe SCHOLAR, Warszawa.

Informacja na temat sytuacji na obszarach wiejskich i w rolnictwie 2008, Ministerstwo Rolnictwa i Rozwoju Wsi, Departament Programów i Analiz, Warszawa.

Informacja o stanie infrastruktury technicznej wsi. Raport roczny 2010, 2011, Ministerstwo Rolnictwa i Rozwoju Wsi, Warszawa.

Januszek H., Sikora J., 2008, Socjologia pracy, Wydawnictwo Akademii Ekonomicznej w Poznaniu, Poznań.

Kocik L., 2001, Trauma i eurosceptycyzm polskiej wsi. Drukarnia Narodowa SA, Kraków. Polska wieś i rolnictwo 2005. Raport z badań, 2005, Ministerstwo Rolnictwa i Rozwoju Wsi, Warszawa. Polska wieś i rolnictwo 2013. Raport z badań, 2013, Ministerstwo Rolnictwa i Rozwoju Wsi, Warszawa.

Sikora J., 2012, Agroturystyka. Przedsiębiorczość na obszarach wiejskich 2012, Wydawnictwo C.H. Beck, Warszawa.

Sikora J., 2014,Warunki życia mieszkańców wsi po wstapieniu do Unii Europejskiej, [w:] N. Drejewska (red.), Rolnictwo, gospodarka żywnościowa, obszary wiejskie - 10 lat w Unii Europejskiej, Wydawnictwo SGGW, Warszawa, s. 185-195.

\section{Summary}

Basic criteria that determine satisfaction and dissatisfaction among inhabitants of rural areas concerning their places of residence compared to living in cities include features of technical, functional and social infrastructure. Poland's membership in the European Union offers great opportunities to improve such infrastructure in rural areas. The aim of this paper is to present the causes for satisfaction and dissatisfaction of living conditions among inhabitants of rural areas.

For comparative purposes, assumed evaluation encompassed the period of 2005-2013. The findings of the study demonstrated that Poland's membership in the European Union results in increasingly poor social, technical and functional infrastructure. However, regardless of many deficiencies of both types of infrastructure, inhabitants of rural areas show high level of satisfaction concerning their place of residence.

The basis for compiling this paper was analysis of subject-related literature and secondary source materials containing results of nationwide Polish empirical studies presented in research reports. Analysis of other source materials was also employed. 
http://rcin.org.pl 